\title{
Çanakkale Çimenlik Kalesi’nin Tarihi Kentsel Peyzaj Elemanı Olarak İrdelenmesi
}

\author{
Füsun Erduran Nemutlu
}

Çanakkale Onsekiz Mart Üniversitesi, Mimarlık ve Tasarım Fakültesi, Peyzaj Mimarlığı Bölümü

Sorumlu yazar: fusunerduran@gmail.com

Geliş Tarihi: 02.07.2020

Kabul Tarihi: 24.02.2021

\section{Öz}

Çimenlik Kalesi, Osmanlı İmparatorluğu'nun yükselme döneminde ilk padişah olan Fatih Sultan Mehmet (II. Mehmet-1451-1481) tarafından yaptırılmıştır. Çanakkale boğazından İstanbul'a gelebilecek savaş gemilerini engellemek amacı ile inşa edilmiştir. Çanakkale boğazının en dar yerinde, Gelibolu yarım adasındaki Kilitbahir Kalesi ile karşılıklı olarak planlanmıştır. Çalışmanın amacı, Kale'nin kent dokusu bütününde tarihi peyzaj elemanı olarak irdelenmesidir. Bu doğrultuda kale ve park alanı, mekânsal, işlevsel ve estetik açıdan analiz edilerek öneriler getirilmiştir. Çalışma sonucunda kale ve park alanının kentsel gelişimden kopuk olduğu, yoğun olarak turizme yönelik kullanıldığı ve park alanının bitkisel tasarım, bitki türü ve niteliği açısından yetersiz olduğu belirlenmiştir.

Anahtar Kelimeler: Çanakkale, Kale-i Sultaniye, Kentsel peyzaj tasarımı, Tarihi peyzaj

\section{Examination of Çanakkale Çimenlik Castle as a Historical City Landscape Element Abstract}

Çanakkale Province has a historical importance from the ancient period to the present day. Thus, the urban area bears the traces of different civilizations and historical events. It was established on both sides of the Bosphorus, which separates the continents of Europe andAsia and carries its name. It has a geography that admires the world. Çimenlik Castle was built by Fatih Sultan Mehmet (II. Mehmet-1451-1481), the first sultan during the rise of the Ottoman Empire. It was built to prevent warships that can come to Istanbul from the Dardanelles. It was planned mutually with the Kilitbahir Castle on the Gelibolu peninsula, in the narrowest part of the Dardanelles. Çimenlik Castle played a very important role in the First World War (1914-1918). The development of the city has been formed around the castle since these periods. Today, the Çimenlik Castle, which is evaluated with in the scope of the historical site and located in the city center, is managed by the Çanakkale Bosphorus and Garrison Command and has been opened for tourism-recreation. The aim of the study is to examine Kale as a historical landscape element in the whole urban texture. Accordingly, suggestions were made by analyzing the castle and park area in terms of spatial, functional and aesthetic aspects. As a result of the study, it has been determined that the castle and park area is disconnected from urban development, it is used intensively fo rtourism, and the park area is insufficient in terms of plant design, plant type and quality.

Keywords:Çanakkale, Kale-i Sultaniye, Historical landscape, Urban landscape design

\section{Giriş}

Çanakkale ili, bölge ölçeğinde antik dönemden günümüze tarihi öneme sahiptir. Kentsel alan açısından da farklı medeniyetlerin ve tarihi olayların izlerini taşımaktadır. İl, Avrupa ve Asya kıtalarını birleştirecek şekilde konumlanmış olup, eşsiz boğaz manzarası ile tüm dünyayı kendine hayran bırakan bir coğrafyaya sahiptir. Bu nedenle kentin kullanımında ve gelişiminde sahip olduğu hassas tarihi-kültürel değerlerin korunması çok önemlidir.

Tarihi kentsel alanlar, geçmişin canlı tanıkları olup, yazılı kaynaklarda var olmayan bilgileri öğrenmemizi sağlar ve nesiller arasındaki devamlılığı sağlarlar (Çelik ve Yazgan, 2009). Bu nedenle tarihi yapı ve mekânların günümüz kullanımına uyarlanması, tasarımı, yönetimi ve tanıtılmasında sadece yapisal olarak değil, çevreleri ile bir bütün olarak değerlendirilmesi zorunludur. Bu kapsamda incelenen "Çimenlik Kalesi ve Park Alanı", günümüzde hem açık müze hem de kültürel etkinlik alanı olarak Çanakkale'nin önemli kentsel odak noktasıdır. 
Bölge tarihinde kentin ve boğazın savunulmasında kullanılan Çimenlik Kalesi, Fatih Sultan Mehmet devri eserlerindendir ve çevresi kentin ilk yerleşim alanıdır. Günümüzde ise kale ve park alanı tarihi değeri yanı sıra, rekreasyonel potansiyelinin yüksek olması ile değer taşımaktadır. Kale çevresindeki yapılar ve park alanı sergi, konser ve konferans gibi kültürel etkinlikler için yılın her dönemi yoğun olarak kullanılmaktadır. Ancak alan kent kimliğinin bir parçası olarak peyzaj mimarlı̆g 1 açısından niteliğine ve işlevlerine uygun bir tasarıma, yeterli donanımlara ve bitkisel kompozisyonlara sahip değildir. Can (1993) tarihi alanlar ile ilgili çalışmasında bu durumu, koruma sadece yıkıma engel olarak mevcut değerleri gelecek nesillere aktarmanın ötesinde çok daha geniş işlevler yüklenmektir şeklinde açılamaktadır. Bu anlayışı oluşturabilmek için ihtiyaç olunan işlevler belirlenmeli ve disiplinler arası çalışılmalıdır. Ayrıca tarihi alanları koruma yaklaşımı, tüm kentsel kullanım alanlarının doğru yönetilmesi ile sürdürülebilir olacaktır. Aksi takdirde yükselen yapılar arasında kaybolarak etkileri küçülecek ve kent kimliğinden uzaklaşacaktır.

Kentlerin kendine özgü nitelik taşıyan; fiziksel, kültürel, sosyo-ekonomik, tarihsel ve bilimsel faktörlerle şekillenen alanları kente kimlik kazandırır ve sosyal açıdan ortak kimliğin parçalarını oluştururlar (Özsüle, 2005). Ancak kentler, fiziksel, sosyal ve ekonomik açıdan çok dinamiktir ve kültürel peyzaj değerlerinin kaybı ve değişimi de belirgindir (Antrop, 2004). Bu nedenle kentsel kültürel envanterler bilimsel verilerle ortaya konularak yıllara göre değişimleri analiz edilmelidir. Elde edilen veriler yerel yönetimlerin ve kurumların çalışmalarını yönlendirecek, peyzaj yönetimi ve politikaları oluşturmalarını sağlayacaktır.

Tarihi nitelik taşıyan kentsel yerleşimlerin dönemlere bağlı olarak kültürel değerlerinin ortaya konulması çok önem taşımaktadır. Çünkü tarihi mekânların, günümüz kentsel gelişme sürecindeki nüfus artışı, kentleşme, çevresel bozulma, afet, iklim değişikliği, artan eşitsizlik ve yoksulluk gibi sorunların etkisinde hızla bozuluma uğraması kaçınılmazdır (Çelik Çanga ve Erduran Nemutlu, 2020). Aynı zamanda günümüzde kentler teknolojiye ve betonlaşmaya teslim olmakta, fiziki çevre özgünlügünü ve kültürel anlamını hızla kaybetmekte, bazen de turizm kullanımının beklentileri doğrultusunda en yüksek kar elde etme felsefesi ile şekillenmektedirler. Çanakkale kentinde de bu sorunları görebilmekteyiz. Bu sorunlardan en önemlisi kent merkezinde yer alan ve kente kimlik kazandıran Çimenlik Kalesi'nin çevresinde hızla yükselen yapılaşma ile kuşatılması ve kent bütününden kopuk olarak kendi içinde kalmaya başlamasıdır. Aynı zamanda kalenin kentsel tasarımdaki görsel etkisinin zamanla kaybolmaya başlaması ve peyzaj tasarımı açısından yetersiz olması, bu çalışmanın yapılma gerekçesini oluşturmuştur.

Çalışmanın amacı, Kale'nin kent dokusu bütününde tarihi peyzaj elemanı olarak irdelenmesidir. Çalışmada kale ve park alanı, mekânsal, işlevsel ve estetik açıdan analiz edilerek tasarım açısından sorunları ve ihtiyaçları belirlenmiş, öneriler getirilmiştir Bu doğrultuda zamanın izlerinin gelecek nesillere sürdürebilir olarak aktarımının önemi de ortaya konulmuştur.

\section{Kentsel Tasarımda Tarihi Alanların Önemi}

Tarihi yap1 ve alanlara sahip kentlerde, sosyo-kültürel ve estetik kaynaklar tüm kenti etkilemektedir. Bu noktada kentsel alanlarda koruma-kullanma dengesinin göz önünde bulundurulmas1 kaçınılmazdır. $\mathrm{Bu}$ dengeyi sağlayacak olan, geçmişten günümüze aktarılan bu değerlerin günümüz şartları ile kullanımlarının yönetilmesi veya çağımıza dönüşümüdür.

Tiesdell ve ark. (1996), 'değişimi yönetmek' konusunda, tarihi alanları değişimin içine olduğu gibi bırakmak ne kadar yanlış ise koruma niyetiyle onları izole etmekte o kadar yanlıştır saptamasında bulunmaktadır. Tarihi alanlarda da bu değişimin ve izin verilen müdahalenin derecesi esastır. $\mathrm{Bu}$ değişim ve müdahale kontrollü ve planlı olduğu takdirde hem tarihi değere sahip çevrelerin korunması hem de bugünün gereksinimlerine cevap veren mekânların oluşturulması mümkündür (Ardıçoğlu, 2014).

Tarihi alanlar genelde kentin ilk yerleşim alanı olarak kentin çekirdeğini oluşturmaktadır. Kent tarihinde önemli olaylara sahne olan bu mekânlar kentsel tasarımda günümüz ihtiyaçlarına göre işlevlere sahip olduğunda hem kullanıcılarına tarihi yerinde tanıtarak kent hafizası niteliği taşır, hem de kentsel peyzaj tasarımının ilgi odağı olabilirler. Ayrıca öğretici, ilgi çekici olması yanı sıra ortak tarihi paylaşan bireyler arasında duygusal bağlantı kurulmasını sağlayarak sosyal ilişkileri de olumlu yönde etkilerler. Bu yönden Çanakkale Çimenlik Kalesi, kentsel tarihi önemi yanı sıra rekreasyonel açıdan da kentli için önemli bir yapısal elemandır. Bu nedenle kente kimlik kazandıran alan, tarihi olayların anlamlandırılması yönünde tasarımlarla zenginleştirilmelidir. 
Açık hava müzesi niteliğinde olan tarihi kent mekânları, tarihi kent merkezlerinin ticari, yönetsel ve diğer işlevlerle aşırı yüklenmesine neden olabilirler (Ahunbay, 2004). Bu durum kentlere göre değişiklik gösterse de genelde bu aşırı yükler ölçeğin kaybedilmesine, kent kimliğinin değişmesine yol açabilir. Bu bağlamda kale ve yakın çevresi, kente gelenlerin en yoğun ziyaret ettiği ve bazen taşıma kapasitesi üzerinde kullanılan bir alandır. Kalenin modern kent dokusu arasında kaybolmasının engellenmesi için kentsel bütünlük içinde kültürel çalışmalar yapılmalıdır. Unutulmamalıdır ki kültürel kaynak ve değerler kullanılmadıkça ve geleceğe taşınmadıkça kaybolmaya mahkûmdur. Bu bağlamda kalenin yapısal özellikleri, açık alanlarının nitelikleri ile bir arada incelenmeli ve kent ile bağlantısı geliştirilmelidir.

Kaleler askeri önemi olan şehirlerde genelde, stratejik yol üzerinde, geçit ve dar boğazlarda, gerekli askeri kuvveti barındırarak, savunma ve güvenliği sağlamak için yapılan kalın duvarlı, burçlu, mazgallı yapılardır. Kale mimarisi, tarihin ilk devirlerinden itibaren tekniğin ve askerlik ile savaş usullerinin ilerleyişine uyarak gelişme gösterse de benzerlikleri vardır (Anonim, 2016 a). Ancak bugünkü şartlarda artık kalenin savunma amaçlı kullanımı gerekli değildir ve müze niteliğindedir. Kentsel açıdan kent tarihinin yerinde yaşatılmasını ve kentlinin ortak geçmişine sahip çıkma duygusunu artıran önemli bir elemandır. Ayrıca turizm ve rekreasyonun en önemli odak alanıdır. $\mathrm{Bu}$ nedenle çalışma alanı ve yakın çevresinin kentsel gelişim ile bütünleşik planlaması yapılarak kente sosyal, ekonomik ve estetik yönden katkı sağlanabilir.

Tarihi kent planlaması ile ilgili The Council of Europe tarafından tarihi nitelikli kentsel alanlar ve yapılar için birçok proje geliştirilmiştir. Bunlardan biri 1998-2001 yıllarında, tarihi Tiflis (Gürcistan) kentinin pilot bölge seçildiği, miras varlıklarının halka tanıtılması ile tarihe bağlılık yaratılan, ve kentin tamamını kapsayan kent planlamasının yapıldığı çalışmadır (Bouzou, 2018).

\section{Materyal ve Yöntem}

$\mathrm{Bu}$ çalışmanın ana materyalini, Çanakkale ili, Merkez ilçesinde yer alan Çimenlik Kalesi ve Park alanı oluşturmaktadır. Yardımcı materyal olarak alana ilişkin literatür bilgileri, resmi ve özel yazılı belgeler, yerinde çekilen fotoğraf ve analizler kullanılmıştır. Türkiye'nin kuzey-batısında,

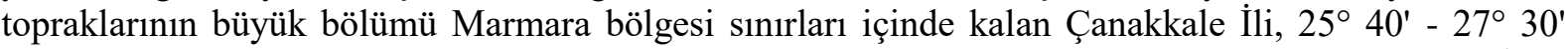
doğu boylamları ve $39^{\circ} 27^{\prime}-40^{\circ} 45^{\prime}$ kuzey enlemleri arasında yer alır. Yüz ölçümü $9.887 \mathrm{~km}^{2 \prime} \mathrm{dir}$. İl'in en önemli konumsal niteliği, Asya (Anadolu-Biga yarımadası) ve Avrupa (Trakya-Gelibolu yarımadası) kıtalarında topraklarının bulunması ve dünyada az rastlanan ve kendi adını taşıyan boğaz ile ikiye bölünmüş olmasıdır (Anonim, 2017). Çimenlik Kalesi, Fevzi Paşa Mahallesinde yer almakta olup, 1976 yılında "Anıtsal Yapı" olarak sit statüsüne alınmıştır (Tombul, 2015). Kalenin içinde yer aldığ 1 Fevzi Paşa Mahallesi ise, Edirne Koruma Kurulu tarafindan, 1995 yılında kentsel sit ilan edilmiştir. Koruma amaçlı imar planı Çanakkale Belediye Meclisi tarafından 15 Temmuz 1996 tarihinde katılımcı bir süreçle hazırlanmış olup, 14 Kasım 1996 tarihinde Edirne Koruma Kurulu tarafından onaylanmıştır (Anonim, 2013) (Şekil 1).
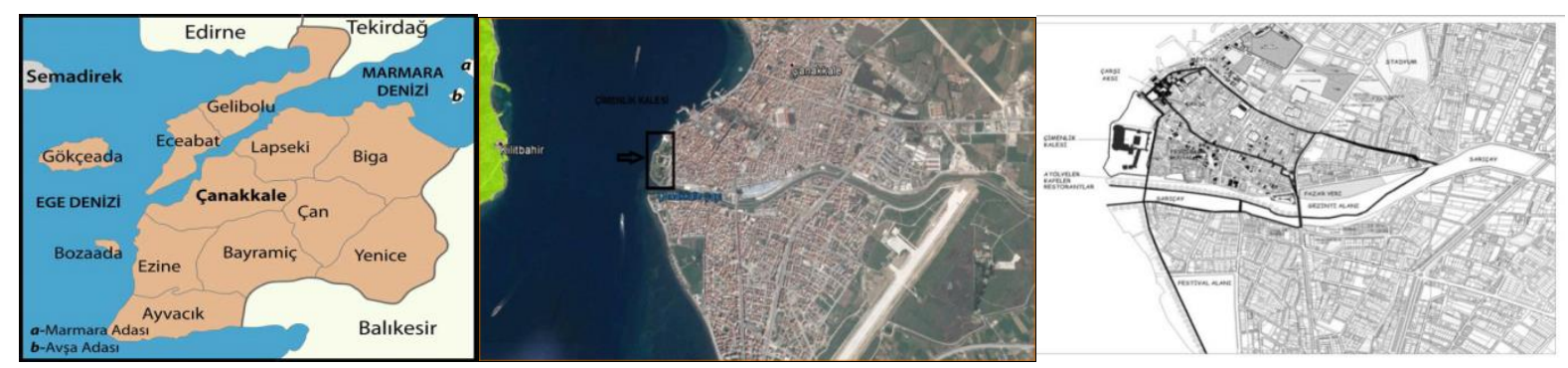

Şekil 1. Çanakkale Boğazı'nın iki yakasında Çimenlik ve Kilitbahir Kaleleri’nin konumu (Anonim, 2016b); Kale bölgesi kentsel sit sinırları (Anonim, 2011).

Çalışmanın yönteminde ilk aşamada konu ile ilgili, yayınlar ve literatür bilgileri elde edilmiştir. Çimenlik Kalesi'nin geçmişten günümüze kadar kullanımı ve tarihiyle ilgili sözlü, yazılı ve resmi belgeler ilgili kuruluşlardan temin edilerek değerlendirilmiştir. İkinci aşamada, alanın kullanımı geçmişten günümüze tarihi açıdan incelenmiş, alan yerinde gözlemlenerek tasarımı irdelenmiş ve detaylı fotoğraflar çekilmiştir. Üçüncü aşamada, kalenin çevre ile bağlantıları, kent dokusundaki rolü, 
fiziki açıdan işlevleri mekânsal olarak yapılan analizler yardımı ile irdelenmiştir. Aynı zamanda park alanındaki mevcut bitkilerden örnekler toplanarak teşhis edilmiştir. Son aşamada ise analizler doğrultusunda alanın peyzaj mimarlığı açısından değerlendirilmesi yapılarak tüm bilgiler sentezlenmiş, günümüz şartlarına uygun olarak ihtiyaçlar doğrultusunda öneriler getirilmiştir. Ayrıca alanın rekreasyonel kullanımına yönelik Auto CAD ve 3ds max (2010) programı kullanılarak, kıyıda bir oturma alanı tasarımı ve onun önünde boğazda yaşanan çarpışmayı açıklayan haritanın zemine işlendiği küçük bir meydan önerisi yapılmıştır.

\section{Bulgular}

Günümüzde Milli Savunma Bakanlığı, Boğaz ve Garnizon Komutanlığı tarafindan yönetilmekte olan alanın çevre ile bağlantıları Şekil 2'de görsel olarak belirtilmiştir. Kentsel alanda yer alan ve çalışma alanı ile yakın ilgili olan alanlar harita üzerinde işaretlidir. Tüm kent dokusu dikkate alındığında çalışma alanı konum olarak kentsel düğüm noktası niteliğindedir. Günümüz Çanakkale'sinin hızlı gelişen yapı adaları arasında kütlesel etkisini koruyamamış olsa da kıyıda Kilitbahir Kalesi ve Boğaz manzarası hakimiyeti ile çok değerli bir alandadır.

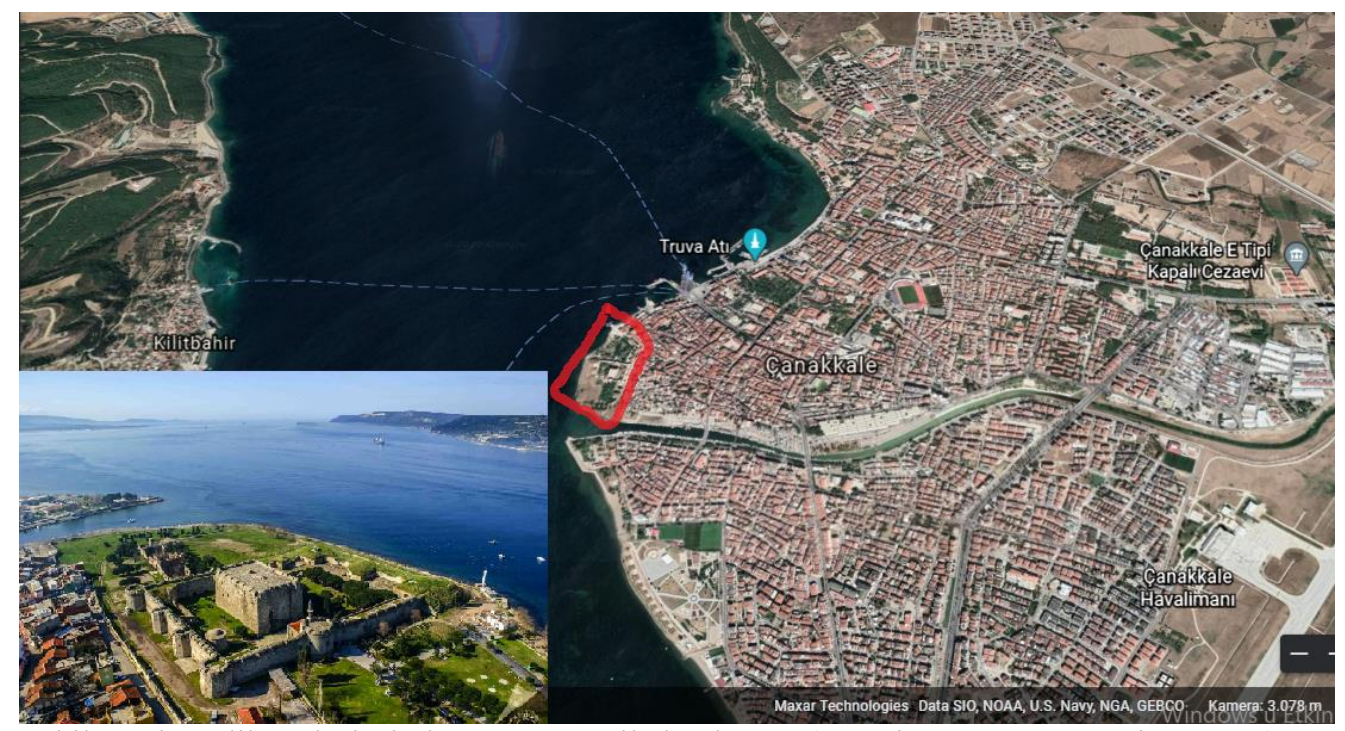

Şekil 2. Çimenlik Kalesi'nin kent ve çevre ile bağlantısı (Anonim 2020 ve Anonim 2019a)

\section{Çimenlik Kalesi’nin Tarihi Gelișimi ve Kentsel Alanda Önemi}

Günümüzde Çimenlik Kalesi olarak isimlendirilen Kale, tarihi dönemlerde 'Kala-i Sultaniye', 'Boğaz Hisarı', 'Çanakçılar Kalesi' olarak isimler almıştır. Osmanlı dönemi resmi kayıtlarında ise Çanakkale ili ve Boğazı'na Kala-i Sultaniye (en kuvvetlisi) denilmiştir (Hatip, 2009). Bu ismin söylenmesi zor olduğundan zamanla değişime uğramıştır. Utkular (1953)'ın çalışmasında ise Kale'nin çevresinin yeşilliğinden esinlenilerek 'Çimenlik' adı verildiği belirtilmektedir. Fatih Sultan Mehmet, Çanakkale Boğazı'nın İstanbul'un savunulmasındaki öneminden dolayı,1462-1463 yıllarında, boğazın en dar yerinde, Rumeli sahilinde (Sestos) Kilitbahir Kalesi'ni, Anadolu sahilinde ise (Abydos) Çimenlik Kalesi'ni karşılıklı olarak inşa ettirmiştir (Hatip, 2009). Boğazın bu kısmı olası saldırılarda düşman gemilerinin yakalanabilmesi için en uygun jeomorfolojik özelliktedir (Şekil 3).

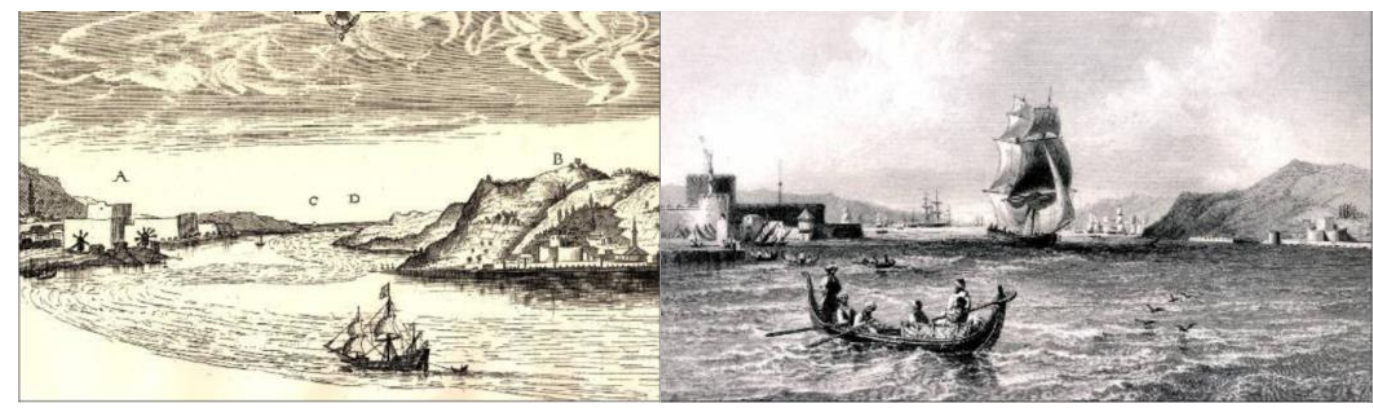


Şekil 3. Çanakkale boğazında Sestos ve Abydos Kaleleri'nin 1664 yılı görüntüsünü yansıtan gravürleri. (A: Çimenlik, B: Kilitbahir Kaleleri) (Sevim, 2002).

Çimenlik Kalesi, 1915 Çanakkale Deniz Savaşları'nda Merkez Savunma Grubu'nun sevk ve idare bölgesi olmuş, İngiliz ve Fransız gemileri tarafından bombardımanına tutulmuş, ancak yıkılmamıştır. İngilizler'e ait Queen Elizabeth gemisinden atılan, $38 \mathrm{~cm}$ 'lik bir mermi, bonetlerden birinin duvarına saplanmış ve günümüzde de sergilenmektedir (Hatip, 2009). Kale içinde Jandarma Efrat Okulu kalıntıları da bulunmaktadır.

Kale'nin tarihi süreçte yapısal onarımı ve yönetim durumu:

1- Sur duvarlarının güçlendirilmesi: 1551, 1839, 1861, 1876 (Tombul, 2015).

2- Otantik yapısına sadık kalınarak onarımının yapılması: 1966-1970.

3- Deniz Kuvvetleri Komutanlığı'na devredilmesi: 1982.

4-Kale girişindeki iç mekanın yeniden düzenlenerek gravür, harita ve fotoğrafların yer aldığı panolarla tanıtım ve tarihinin anlatılmasi: Aralık 2001.

5- İç Kalenin ikinci katının onarılarak açılması: 11 Mart 2005 (Hatip, 2009).

6- T.C. Kültür Bakanlığı tarafından özgün yapısına uygun olarak yeniden restore edilmek üzere 9.05.2011 tarihinde Milli Savunma Bakanlığ ile protokol imzalanmas1 ve 02.03.2015 tarihinde restorasyonunun yap1lmas1 (Anonim, 2015).

7- Boğaz ve Garnizon Komutanlığ tarafından 2018 yılında alanın yeniden restore edilmesi. Kafe yapılması ve Gemi Acar'ın alana yerleştirilmesi. Açık alanda denizcilik terim ve elemanlarının eğlenceli bir şekilde tanıtıldığı donanımlara yer verilmesi.

Çimenlik Kalesi'nin kentin gelişimi ve dokudaki önemini incelediğimizdekent merkezinde oluşan yerleşimlerin onun etrafinda olduğunu görmekteyiz. Uzunçarşı1ı (1991)'nın belirttiğine göre, boğazın savunulmasında görevli asker ve idareci sivil memur olan müslümanlar, ilk olarak Fatih Camisi civarındaki 'Cami-i Kebir' mahallesini, kalenin yapımında çalışan Romanlar ise 'Çay Mahallesi'ni oluşturmuşlardır. Daha sonra 'Rum ve Ermeni Mahalleleri' kurulmuştur. Çanakkale Belediyesi arşiv kayıtlarından elde edilen bilgiye göre aynı bölgede, 1492'de İspanya'dan geldikleri sanılan Yahudiler de yerleşmiştir.

Kayıtlara göre, 1840'taki nüfus sayımında şehirde dört müslüman ve üç gayr-imüslim mahallesi bulunmaktadır (Anonim, 1981).

\section{Çimenlik Kalesi ve Park Alanının Analizi}

Kale, kent merkezinde olup, kente gelenlerin yürüyerek kolayca ulaşabileceği bir konumdadır. Kentin trafik ağı analizi incelendiğinde en yoğun kullanılan ve Avrupa yakasına geçişin sağlandığı iskele yoluna bağlı olan, daha az yoğun araç trafiği üzerindedir (Şekil 4).

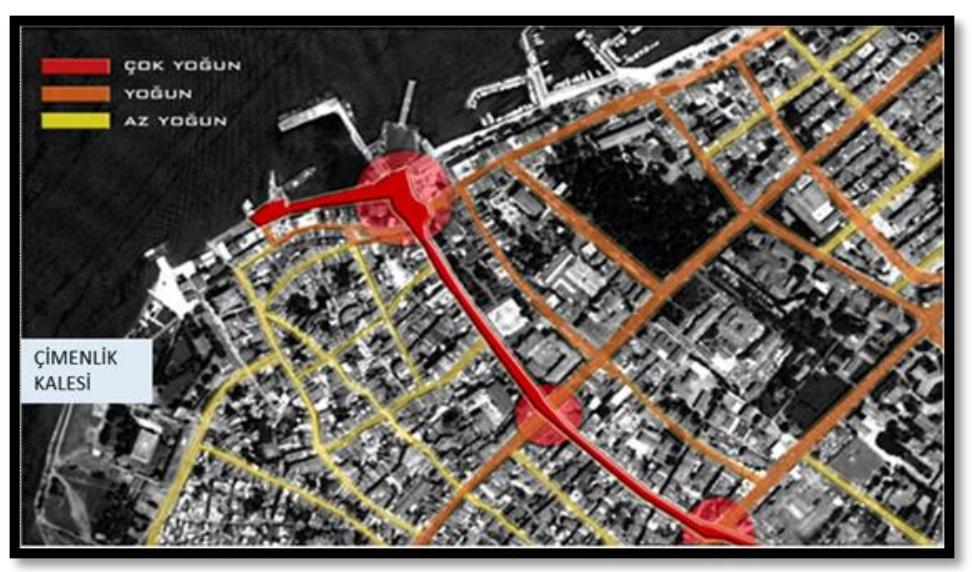

Şekil 4. Çimenlik Kalesi'nin kent ulaşımındaki analizi (Anonim, 2012).

Günümüzde kale ve park alanı tarihi değeri, manzarası ve açık-yeşil alan potansiyeli ile önemli kültürel peyzaj elemanıdır. Yıllık ziyaretçi sayısı, Kale idaresinin belirttiğine göre yaklaşık 300 bin olup, turizm yanı sıra kent okulları tarafından organize turların yapılması söz konusudur. Açık alanda Çanakkale Deniz Savaşı ile ilgili bilgiler, savaşta kullanılan, farklı uluslara ait toplar, denizaltı 
ve mayınlar, komutanların büstleri, Nusret Mayın Gemisi maketi sergilenmektedir. Girişten itibaren yönlendirmeler mevcuttur. Girişin sol tarafında hediyelik eşya satışı, kafeterya, sergi ve konferans salonu, sosyal ve kültürel etkinlikler için yoğun kullanılmaktadır. Yapılan son restorasyonlar ile açık ve kapalı müze niteliği zenginleştirilmiş ve açık alanda çocuklara yönelik tanıtım alanları yapılmıştır. Sergi salonunun girişe bakan duvarı Çanakkale Deniz Zaferi'nin 90. yılı anısına yapılan seramik kabartma pano ile kaplıdır (Şekil 5). Bina girişinde müze gemi Acar, cam bir platformun üzerine 2018 y1lında yerleştirilerek tanıtılma açılmıştır. Acar, ulu önder Mustafa Kemal Atatürk'ün, İstanbul Boğazı'nda gezinti ve 'Savarona' yatına gitmek için kullandığı gezinti teknesidir. Gemi Acar, 1936-37 yıllarında Almanya'da yapılmış olup, Mustafa Kemal Atatürk tarafından İstanbul Boğazında gezinti yapmak ve Savarona Yatı'na gitmek için kullanılmıştır (DHA, 2018) (Şekil 6).

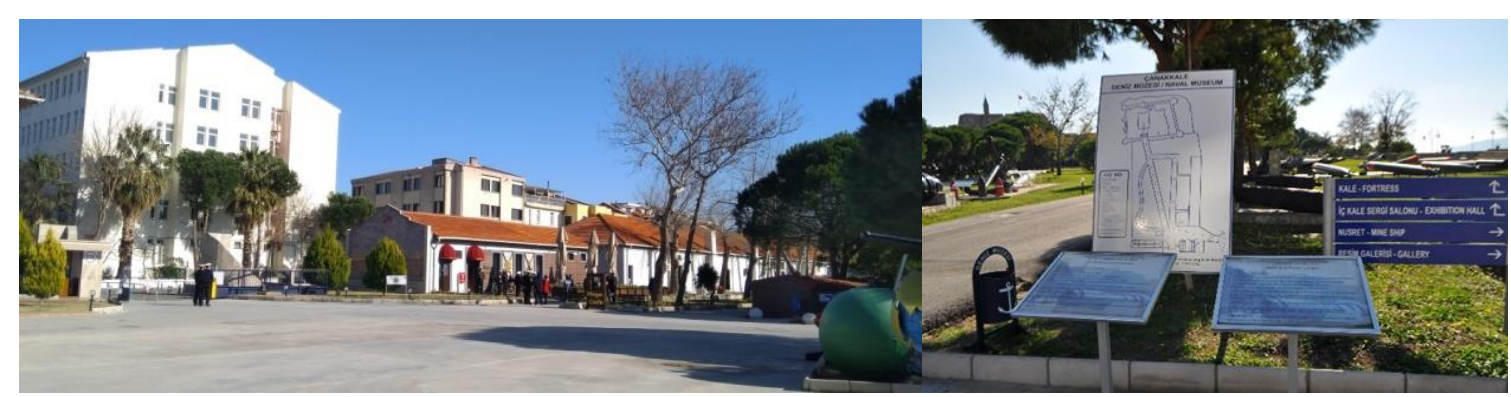

Şekil 5. Çimenlik Kalesi girişi (2020)

Kalenin kuzey duvarının cadde bölümüne bakan tarafı otopark olarak kullanılmakta ve bu durum araç yoğunluğuna neden olmaktadır. Araçlar geçişi zorlaştırmakta, tehlike yaratmakta olup diş duvar görsel olarak kirli, çok bakımsız ve yıkık durumdadır. Alana sadece sahil yolundan giriş çıkış yapılmaktadır. Alanın devamında kentleşme güneydoğu yönüne doğru gelişim göstermiştir. Ancak kale, dikenli tel ve yüksek duvarlarla çevrelenerek bu bağlantıdan koparılmış olup, askeri bir müze niteliğindedir. Kale duvarının arkasındaki yol oldukça dar ve geçişe kapalı durumdadır. Kale önünden sahilden eski bir yol vardır ancak artık kapalıdır. Kale'den Sarıçay'a uzanan ara sokakların düzensiz, korku uyandıracak derecede güvensiz olması ve tanımsız bölgeler bulunması, Kale'nin kentin yeni gelişim alanı ile bağlantısını koparmaktadır. Bu nedenlerle Kale, rekreasyon açısından ve kent içi bağlantılar açısından kentli kullanımının daha az olduğu tarihi bir alandır (Şekil 6). Oysa kentlerin en önemli simgeleri olan kaleler kentlinin tarihi mekansal açıdan algılamasını sağlayan önemli alanlardır. $\mathrm{Bu}$ yönden Ankara Kalesi, Diyarbakır Kalesi gibi kentli ile bütünleşmiş örnekler verilebilir. Ayrıca Avrupa'da Osmanlı İmparatorluğu'nun izlerini yansitan önemli kaleler de kentlerin odağı durumundadır ve günlük yaşam ile iç içedir. Bu örnekler ile karşılaştırıldığında alanın kent ile bütünleşmediği görülmektedir. Günümüzde askeri kışla olarak alanda personel bulunması ve askeri deniz müzesi elamanlarının korunması gereğinden yönetimi Boğaz Garnizonu'na bağlıdır. Bu durum alanı toplumdan koparmaktadır. Yeni yapılan kafeterya ve rekreasyon elemanları park alanının kullanımını artıracaktır.

Çalışma alanının sahilinde yer alan, mimari yapısı ile ilgi çeken estetik yönetim binası 1954 tarihinde yapılmıştır. Diğer mimari niteliği ile ilgi çeken yapı ise müzedir ve 1927 tarihinde yapılmıştır. Park alanında ziyaretçilerin en fazla ilgisini çeken ise, 18 Mart 1915 'Deniz Zaferi'nin kahramanı olan, mayın dökücü Nusret Mayın Gemisi'nin bire bir ölçekli olan maketidir. Ayrıca hemen önündeki kıyı alanında tören alanı, komutan heykelleri ve Çanakkale savaşları anı duvarı vardır. Çanakkale savaşı ile ilgili görseller ve mayın grup komutanı Binbaşı Nazmi Bey ile Nusret Mayın Gemisi komutanı Yüzbaşı Tophaneli Hakkı beyin heykellerinin bulunduğu tören alanı askeri törenlerde de kullanılmaktadır (Şekil 7). 


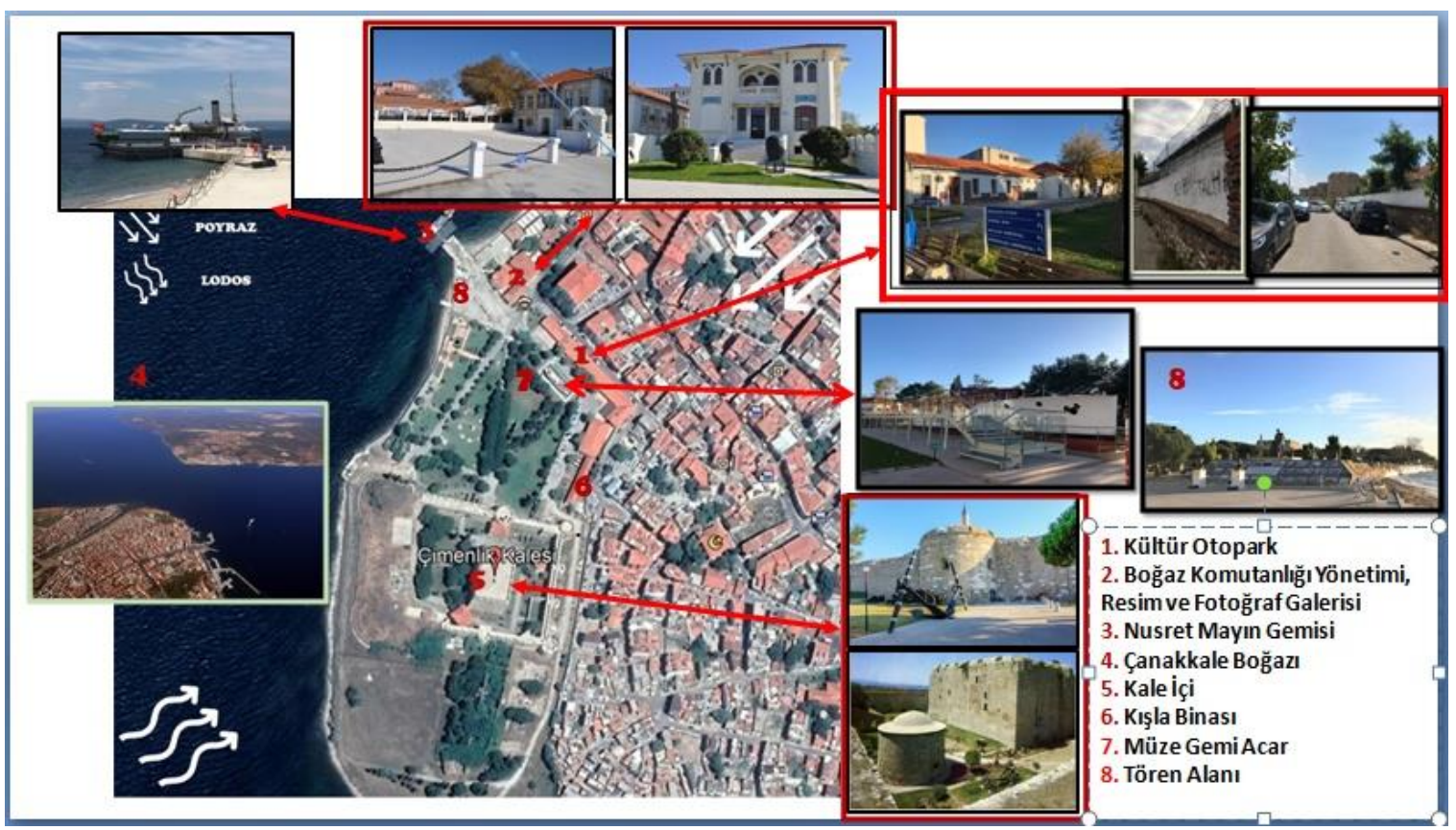

Şekil 6. Çimenlik Kalesi’nde yer alan mekanlar (2020). (Uydu ve hava görüntüleri: Anonim, 2019 b, Anonim, 2020)

Kale ve park alanı kültürel etkinlikler ve konserler için yılın farklı dönemlerinde kullanılmaktadır. Alanda kafeterya ile birlikte, 2020 yılı başında çim alan üzerinde ziyaretçilere ve çocuklara yönelik eğlenceli bilgi panoları yerleştirilmiştir. Ancak alan henüz peyzaj mimarlığı açısından niteliğine ve işlevlerine uygun bir tasarıma sahip değildir. Alan dezavantajlı vatandaşların tekerlekli sandalyeleri ve çocuk arabaları ile kullanımları açısından uygun zemin tasarımına sahip değildir (Şekil 7). Alan kuzeydoğu yönünden poyraz, güney batı yönünden ise lodos rüzgârına açıtır ve buna yönelik koruyucu bitkilendirme yapılmamıştır.

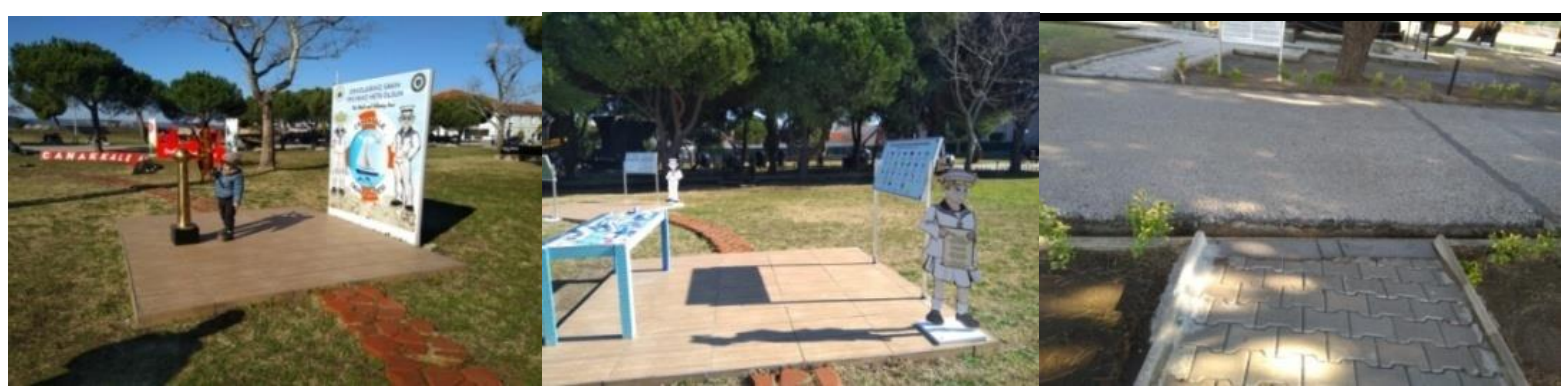

Şekil 7. Park alanında denizcilik terimleri ve malzemeleri tanıtımı (2020)

Kale içinde ve Nusret Mayın Gemisinde ise savaş dönemine ait anlatımlar ve canlandırmalar yapılmaktadır. Kale içinde yer alan baruthane, gerek mimari yapısı, gerekse kullanım amacı yönünden ender rastlanan yapıtlardan olup günümüzde Piri Reis Galerisi olarak kullanılmaktadır. Baruthanenin yanında kalenin güneybatı iç surlarına bitişik inşa edilmiş halen duvarları duran okul olarak kullanılmış yığma bir bina mevcuttur.

Deniz kıyısında yer alan ve ziyaretçilere tanıtılan Nusret mayın gemisinin orijinali 1962 'de özel sektörce satın alınmış ve Kaptan Nusret adıyla kuru yük gemisi olarak hizmet vermiştir. Ancak 1990 yılında Mersin açıklarında alabora olmuştur ve 1999 yılında bir grup gönüllü tarafindan su yüzüne çıkarılmıştır. Tarsus Belediyesi 2003 yılında gemiyi alarak, Çanakkale Savaşları ile ilgili tanıtımın da yapıldı̆̆ park alanında anıt haline getirmiştir (Şekil 8). Çimenlik Kalesi'nde yer alan Nusret Mayın Gemisi'nin bire bir ölçülerindeki maketi ise İstanbul Tersanesi Komutanlığı tarafından 2011 y1lında inşa edilmiştir (Anonim, 2016c). 

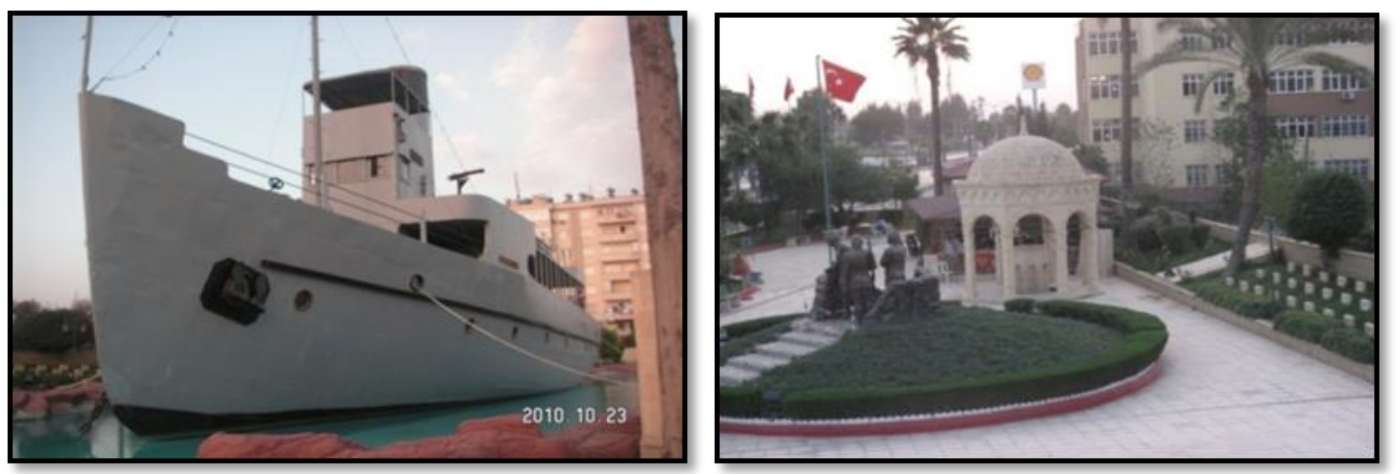

Şekil 8. Mersin Tarsus'da yer alan, Nusret Mayın gemisinin orijinali ve park alanı ( 2010).

\section{Çimenlik Kalesi Park Alanının İrdelenmesi}

Çanakkale kent merkezi, boğaz kıyısı boyunca gelişim göstermiştir ve bu nedenle açık alan potansiyeli açısından yüksektir. Ancak kentsel yeşil alan varlığı nitelik ve nicelik açısından yetersizdir. Çimenlik Kalesi park alanı ise yeşil potansiyeli yüksek olması nedeni ile kent ekosistemi ve rekreasyonu açısından çok önemli katkı sağlamaktadır (Şekil 9).

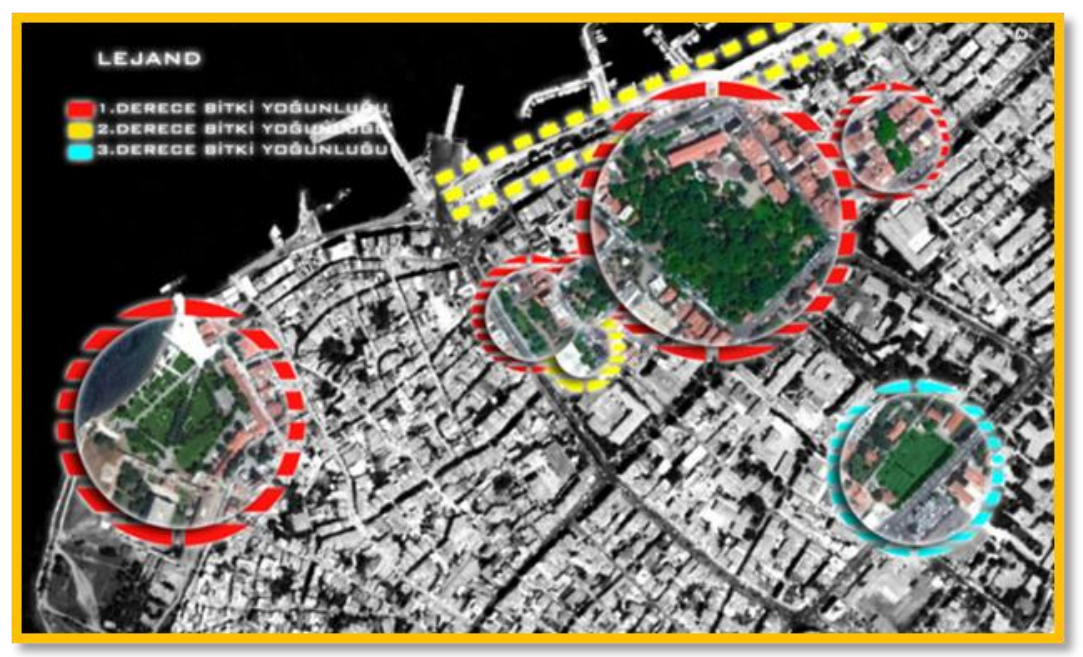

Şekil 9. Kentsel yeşil alan analizi ile Kale park alanı ilişkisi (Anonim, 2012).

Alanda kullanılan peyzaj bitkileri yerinde incelenmiş, Tablo 1'de nitelikleri ve kullanımları açısından analiz edilmiştir. Tabloda bitkilerin Latince, (A) ve Türkçe isimleri (B) belirtilerek, genetik özellikleri (C) ortaya konulmuştur. Bitkilerin sahip oldukları ölçü, form, renk, doku olarak sınıflandırılan tasarım öğeleri (D) dikkate alınarak tasarım ilkelerine göre kullanım durumu analiz edilmiştir. Aynı zamanda sahip oldukları estetik özellikleri de değerlendirilmiştir (E). Buna göre tasarım bitkileri açısından çeşitliliğin çok az olduğu, sadece belli türlerin fazla oranda kullanıldığ belirlenmiştir. Alanda etkin olarak, sirkülasyon sistemini vurgulayan bir bitkilendirme yapılmıştır. Bu kullanım zemin çizgisini üçüncü boyuta taşıdığı için iyidir. Ancak farklı bitki türlerinin tabakalı olarak kullanıldığı, ölçü, renk, doku, biçim yönünden alan kullanımını hem görsel hem de işlevsel olarak destekleyen estetik kompozisyonlara yer verilmemiştir.

Alanda ağırlıklı olarak Kızıl çam (Pinus brutia Henry.) ve Fıstık çamı (Pinus pinea L.) kullanılmıştır. Bunun en önemli nedeni resmi kanallar ile bitki temini yapılması ve bitkisel tasarım için bütçe ayrılamamasıdır. Alana farklı dönemlerde yapılan bakımlar sırasında yeni bitki türleri de dikilmektedir. Yer örtücü, tek ve çok yıllık çiçekler ise giriş bölümünde kullanılmakta olup, mevsimsel olarak çeşitlilik görülmektedir. Alan genel karakter olarak askeri nitelikte olduğu için daha çok kasvetli ve ciddi bir etki yaratılmıştır. Ancak alanın açık hava müzesi olması ve turizm açısından yoğun kullanlması nedeni ile daha renkli tasarımlara yer verilmelidir. 
Tablo 1. Çalışma alanındaki peyzaj bitkilerinin nitelikleri ve tasarım açısından değerlendirilmeleri.

\begin{tabular}{|c|c|c|c|c|}
\hline A- Latince ismi & B- Türkçe ismi & C-Niteliği & $\begin{array}{l}\text { D-Tasarım öğe ve } \\
\text { ilkelerine göre } \\
\text { değerlendirilmesi }\end{array}$ & $\begin{array}{l}\text { E- Estetik açıdan } \\
\text { değerlendirilesi }\end{array}$ \\
\hline Campsis radicans Seem. & Acem borusu & $\begin{array}{l}\text { Sarılıc1, turuncu } \\
\text { çiçekli. Yaprak döken. }\end{array}$ & $\begin{array}{l}\text { İyi. Alanda duvar } \\
\text { arıtma duvarını } \\
\text { kapatmak amacı ile } \\
\text { kullanılmıştır }\end{array}$ & $\begin{array}{lr}\text { İyi. Alanın } & \text { genel } \\
\text { kullanım bölgesi } \\
\text { dışında yer almakta } \\
\text { olduğundan } \\
\text { görülememekte }\end{array}$ \\
\hline $\begin{array}{l}\text { Cupressus arizonica var. } \\
\text { 'glauca'Greene. }\end{array}$ & Arizona Servisi & $\begin{array}{l}\text { Herdem yeşil, pul } \\
\text { yapraklı konifer, ağaç. }\end{array}$ & $\begin{array}{l}\text { Çok iyi, Alanda vurgu } \\
\text { etkisi yaratmıştır. }\end{array}$ & $\begin{array}{l}\text { İyi. Alanın ciddi } \\
\text { konseptine uygundur. }\end{array}$ \\
\hline $\begin{array}{l}\text { C. } \quad \text { sempervirens var. } \\
\text { Pyramidalis Nyman }\end{array}$ & $\begin{array}{l}\text { Piramidal } \\
\text { Akdeniz Servisi }\end{array}$ & $\begin{array}{l}\text { Herdem yeşil, pul } \\
\text { yapraklı konifer, uzun } \\
\text { ağaç }\end{array}$ & $\begin{array}{lr}\begin{array}{l}\text { İyi, } \\
\text { monotonluğa } \\
\text { olmuştur. }\end{array} & \begin{array}{l}\text { Alanda } \\
\text { neden }\end{array} \\
\end{array}$ & $\begin{array}{l}\text { İyi. Alanın ciddi } \\
\text { konseptine uygundur. }\end{array}$ \\
\hline $\begin{array}{l}\text { C. sempervirens } \mathrm{var} \\
\text { horizontalis Mill. }\end{array}$ & $\begin{array}{ll}\text { Dalli Akdeniz } \\
\text { Servisi }\end{array}$ & $\begin{array}{l}\text { Herdem yeşil, pul } \\
\text { yapraklı konife, uzun } \\
\text { ağaç. }\end{array}$ & $\begin{array}{l}\text { İyi, Alanda arka fon } \\
\text { olarak etkilidir }\end{array}$ & $\begin{array}{l}\text { İyi. Doygun koyu etki } \\
\text { yaratmaktadır, ancak } \\
\text { kasvetlidir. }\end{array}$ \\
\hline Euonymus japanica $\mathrm{L}$. & Taflan & $\begin{array}{l}\text { Orta boylu, herdem } \\
\text { yeşil çalı. }\end{array}$ & $\begin{array}{l}\text { Zayıf. Deniz kıyısında, } \\
\text { oturma alanında yaşlı } \\
\text { örnekleri iyi değil. }\end{array}$ & Zayif, yetersiz. \\
\hline E. Japonica var. aurea & Alacalı taflan & $\begin{array}{l}\text { Sarı alacalı herdem } \\
\text { yeşil, orta çalı. }\end{array}$ & $\begin{array}{l}\begin{array}{l}\text { Orta. Sınır } \\
\text { olarak }\end{array} \\
\begin{array}{l}\text { elemanı } \\
\text { girişte }\end{array} \\
\text { kullanılmıştır. Sağlıklı } \\
\text { değiller. }\end{array}$ & $\begin{array}{l}\begin{array}{l}\text { Zayıf, etkisiz, girişi } \\
\text { çarpıcı } \\
\text { getirememiş. }\end{array} \\
\text { hale }\end{array}$ \\
\hline Laurus nobilis L. & Defne & Herdem yeşil ağaçcık. & $\begin{array}{l}\text { Çok iyi. Oturma ve } \\
\text { oyun alanı çevresinde, } \\
\text { tabakalı } \\
\text { bitkilendirmeyi } \\
\text { sağlamış ve insan } \\
\text { ölçeğini korumuş. }\end{array}$ & $\begin{array}{l}\text { İyi. Süs niteliği düşük } \\
\text { bir bitkidir. Tüm yıl } \\
\text { alanda etkisi yoğundur }\end{array}$ \\
\hline Nerium oleander L. & Zakkum & $\begin{array}{l}\text { Herdem yeşil, pembe } \\
\text { çiçekli, uzun çalı. }\end{array}$ & $\begin{array}{l}\text { Çok iyi. Oturma } \\
\text { alanları ve yürüyüş } \\
\text { yolları yakınında. }\end{array}$ & $\begin{array}{l}\text { Çok iyi. Çiçek etkisi } \\
\text { uzun süren rüzgâra } \\
\begin{array}{l}\text { dayanıklı tüm yı } \\
\text { etkili. }\end{array}\end{array}$ \\
\hline Olea europea L., & Zeytin & Herdem yeşil ağaçcık. & $\begin{array}{l}\text { Orta. } \quad \text { Bahçenin } \\
\text { işlevine uygun değil. }\end{array}$ & $\begin{array}{l}\text { Orta.Yapraklarının } \\
\text { rengi tüm yıl etkili } \\
\text { ancak kompozisyon } \\
\text { yapılmamış. }\end{array}$ \\
\hline Platanus orientalis L., & Çınar & $\begin{array}{l}\text { Yaprak döken, uzun, } \\
\text { ağaç }\end{array}$ & $\begin{array}{l}\text { İyi. Gölge etkisi ile } \\
\text { açık müze kullanımını } \\
\text { sağlar. }\end{array}$ & $\begin{array}{l}\text { İyi. Etkili. Dallarının } \\
\text { ve yapraklarının ilginç } \\
\text { görüntüsü ile etkili. }\end{array}$ \\
\hline Pinus brutia Henry. & Kızılçam & $\begin{array}{l}\text { Herdem yeşil, iğne } \\
\text { yapraklı, uzun ağaç. }\end{array}$ & $\begin{array}{l}\text { Orta. Alanda yolu } \\
\text { belirlemiş ama } \\
\text { yaşlı örnekler. }\end{array}$ & $\begin{array}{lrr}\text { Zayıf. Alanı } & \text { çok } \\
\text { kapatmış } & \text { ve } & \text { süs } \\
\text { niteliği yok. } & & \end{array}$ \\
\hline Pinus pinea $\mathrm{L}$. & Fistık çamı & $\begin{array}{l}\text { Herdem yeşil, iğne } \\
\text { yapraklı, uzun ağaç. }\end{array}$ & $\begin{array}{l}\text { İyi. Alanda yolu } \\
\text { belirlemiş. }\end{array}$ & $\begin{array}{l}\text { İyi, etkili. Yumuşak, } \\
\text { çizgileri ile etkili. }\end{array}$ \\
\hline Rosa spp. & Gül & $\begin{array}{l}\text { Renkli çiçekli, yaprak } \\
\text { döken çalı. }\end{array}$ & $\begin{array}{l}\text { Çok iyi. Alanın } \\
\text { hareketlendiriyor. }\end{array}$ & $\begin{array}{l}\text { Çok iyi. Farklı renk } \\
\text { etkileri uzun sürer. }\end{array}$ \\
\hline Rosmarinus officinalis L. & Biberiye & $\begin{array}{l}\text { Herdem yeşil, mor } \\
\text { çiçekli kısa çalı. }\end{array}$ & $\begin{array}{l}\text { İyi. Kullanım yerlerine } \\
\text { dikkat } \\
\text { bakımsız. } \\
\text { yaşlanır. }\end{array}$ & $\begin{array}{l}\text { Çok iyi. Çiçekleri } \\
\text { küçük ama etkili, } \\
\text { yaprakları kokulu }\end{array}$ \\
\hline
\end{tabular}

Park alanında yer alan yapısal donatılar ve zemin kaplaması incelendiğinde bakım onarım yönünden önemli problemler belirlenmiştir. Boğaz manzarasının izlenebilmesi için tasarlanan oturma alanlarına iniş yeri, basamak veya rampa yapılmamıştır ve oturma alanının önünde geçiş yoktur. Ayrıca ters yönde yapılan oturma birimine geçiş verilmemiştir. Mevcut donatılar yetersiz ve eski olup, zemin kaplamaları yürüyüşü ve tekerlekli araç kullanımını zorlaştırmakta ve tehlike yaratmaktadır (Şekil 10). 


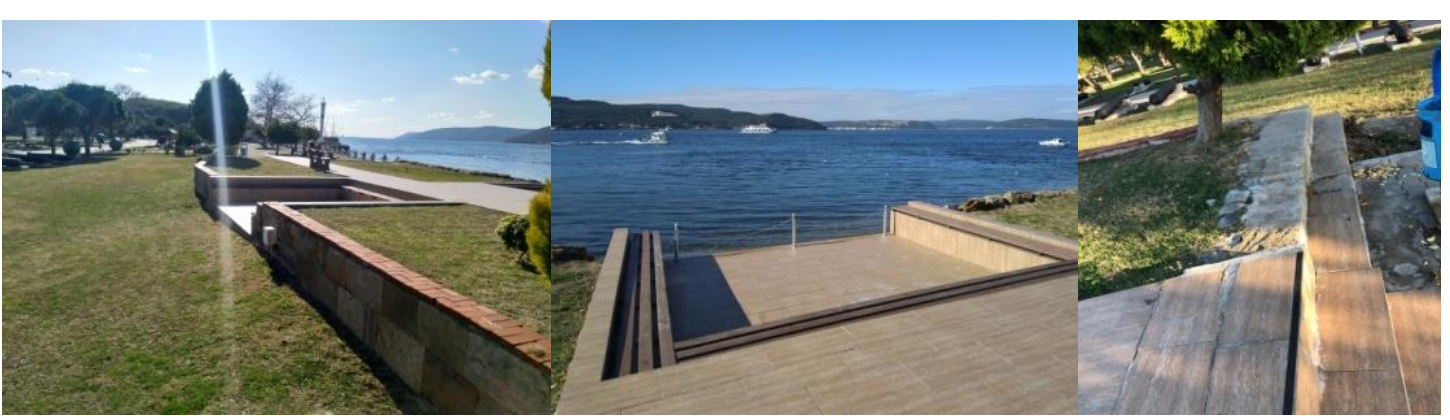

Şekil 10. Park alanı sahilinde oturma üniteleri (2020)

\section{Sonuç Tartışma ve Öneriler}

Kentsel alanların mekânsal hafızası, açık müze niteliği taşıyan tarihi alan ve bölgelerdir. Bu alanların korunarak günlük yaşam ihtiyaçları doğrultusunda kullanılması, kentin kimlik kazanımına katkı sağlamaktadır. Bu nedenle kent ekonomisinin ve turizminin odak alanlarını oluşturan tarihi alanların en önemlilerinden olan kaleler, yakın çevreleri ile ele alınmalıdır. Bu bağlamda çalışmada Çimenlik Kalesi'nin kent dokusundaki rolü geçmişten günümüze fiziki açıdan ve işlevsel olarak irdelenmiştir. Çünkü fiziki çevre kentsel karakteri yansıtmaktadır.

Alan, kentin kuruluşundan günümüze kadar bel kemiği niteliği taşımıştır ve günümüzde hem açık müze hem de kültürel etkinlik alanıdır. Yapılan çalışmada öncelikle Çimenlik Kalesi'nin tarihi ve kültürel açıdan kent gelişimdeki önemi ortaya konulmuştur.

Çalışma sonucunda kalenin yakın çevresindeki yerleşim ile zaman boyutunda farklı yönlerde gelişimi belirlenmiş̧tir. Kentsel sit alanı ilan edilen Kale çevresi, çok hızlı yapılaşmış ve ticari merkeze dönüşmüştür. Kale ise askeri niteliğini korumuş ve kent dokusundan kopuk kalmış, turizm açısından yoğun kullanılmıştır. Yerinde yapılan inceleme ve yetkililerle yapılan görüşmelere göre bunun en önemli nedeni çalışma alanının askeri nitelik taşımasıdır. Askeri yapısı nedeni ile kent ile tam bir bütünsellik taşıyamamıştır.

Çalışma alanının kent ile tam olarak bütünleşebilmesi için sivil idareye geçmesi gereklidir. $\mathrm{Bu}$ durumda bazı tarihi ve askeri malzemelerin güvenliğinin sağlanması, ancak sıkı önlemler ile olabilecektir. Kale park alanı, böylece halkın en yoğun açık alanları kullandıkları gece saatlerinde de hizmet verebilecektir. Bu durumda açık alanda yer alan top, denizaltı vb. malzemelerden bazıları seçilerek ışıklandırılmış cam mobilyalar içinde ve kameralı koruma sağlanılarak sergilenmelidir. Böylece bakım ve sergilenmesi de kolaylaşacaktır. Diğer korunması gereken askeri malzemeler ise girişte yer alan askeri müze ve çevresinde sergilenerek, bu alanın askeri kimliği devam ettirilebilir.

Yapılacak bu düzenleme ile Kale'nin sahilinde yer alan ve daha önce kullanılan eski yol (günümüzde iz olarak bellidir) açılarak, Sarıçay’a geçiş sağlanabilir. Bu tasarım kıyısal rekreasyon alanı olarak kullanım potansiyelini artıracaktır. Aynı zamanda kentin yeni kordon ile bağlantısını da sağlayacaktır. Sarıçay'dan yeni kordona sadece yayaların geçişine izin verilen tarihi yapısal nitelikte bir yaya köprüsü inşa edilerek, sahil yolu eski ve yeni kordon birbirine bağlanarak yaklaşık 7 km'lik bir yürüyüş bandı haline getirilebilir. Bu planlamanın gerçekleştirilmesi ile hem kale bölgesinin yarı askeri kimliği devam edecek, hem de günümüz kentsel gelişimi ile bütünleştirilecektir.

Çelik ve Yazgan (2007)'nın çalışmalarında belirttiği gibi tarihi çevreleri koruma ve yenilemede; tarihsel ve kültürel sürekliliğin sağlanması, amaçlanmalıdır. Bu temel ilke Çimenlik Kalesi için çok önemlidir. Bunu sağlayabilmek için iç kalede günümüzde yapılan canlandırma ve askeri kimlik korunmalıdır. Çimenlik Kalesi sahil bandının kentin yeni gelişim alanı ile bütünleştirilmesi önerisi ise aynı çalışmada belirtilen; kent peyzajının ve geleneksel yerleşim modelinin beraber korunması düşüncesini desteklemektedir. Ayrıca kale park alanını her saat gezilebilme imkânının yaratılması, kentlinin her mevsim kullanımını da artırabilecektir.

Tiesdell ve ark. (1996), nın tarihi alanların yönetimi konusunda vurguladıkları değişimin yönetilmesi olgusu açısından bakıldığında kale, kentten izole edilmiş bir konumdadır. Bu durum alanın askeri niteliğinin devam etmesi ile bağlantılı olmuş, kale müze olarak genelde turizmi desteklemiştir. Ancak kent gelişiminde kentten koparılmadan değişime entegre edilmesi gereklidir. Ardıçoğlu (2014) bu durumu, tarihi kentlerde değişimin ve izin verilen müdahalenin derecesinin iyi 
belirlenmesi ve yönetilmesi ile başarılabileceğini belirtmektedir. Böylece tarih yerinde korunurken bugünün gereksinimlerine cevap veren mekânlar oluşturulabilecektir.

Kale park alanı boğaz manzarasına hakim olduğundan dinlenmek amacı ile yoğun kullanılmakta ve bazı kültürel etkinliklere de açılmaktadır. Alanın mevcut yeşil alanı ise kentsel ekolojiye önemli destek sağlamaktadır. Bu yönleri ile kentsel açıdan doğal ve kültürel potansiyeli çok önemlidir. Ancak alanın bitkisel materyal açısından zenginleştirilmesi ve farklı kompozisyonlar yapılması gereklidir. Deniz Savaşına ait top, mermi vb. malzemelerin tanıtıldığı açık alanda yer alan Kızılçam ağaçları oldukça yaşlı olup gövdeleri çok düzensiz gelişmiş ve eğridir. Bu ağaçların bozuk olanları seyreltilerek daha ferah bir ortam yaratılarak, sunulan askeri malzemelere daha iyi 1şı1k gelmesi sağlanabilir. Bu bitkileri destekleyecek; budanarak şekil vermeye uygun, parlak yaprakları ile top ve diğer siyah renkli malzemeler ile kontrast yaratabilecek, Alev ağacı kullanılabilir (Photinia serratifolia (Desf.) Kalkman). Kıyıdan ve kuzeyden gelen sert rüzgarları kırabilmek amacı ile doğal bitki örtüsünde yer alan, alana iyi uyum sağlayabilecek ve dayanıklı Meşe (Quercus ithaburensis Decne., $Q$. trojana Webb., $Q$. cocsifera L.) ve Erguvan türleri (Cercis siliquastrum L.) kullanılmalıdır. Ayrıca sahilin tuzlu deniz etkisinden etkilenmeyecek ve hoş kokulu çiçekleri ile oturma alanlarına gölgesi ile de etkili olacak İğde ağacı (Eleagnus angustifolia L.) kullanılmalıdır. Sonbaharda kokulu çiçekleri ve herdem yeşil yaprakları ile etkili çalı formunda olan bodur İğde (Eleagnus pungens Thunb.) hem rüzgar etkisini azaltabilecek hem de tarihi objelere iyi bir arka fon oluşturabilecektir. Alanda yol kenarlarına dikilen Taflan bitkileri hastalık ve zararlılara dayanıksız olup tarihi alan ile uyum göstermemektedir. Onun yerine Kurtbağn (alacalı) (Ligustrum ovalifolium var. aurea) ve Şimşir (Buxus sempervirens L.) kullanılması daha uygun olacaktır. Alanda tarihi duvarları kapatan, fazla kasvetli ortam oluşturan ve tarihi yapıların görünümünü zorlaştıran yaşlı ağaçlar gençleştirilmeli, bazılarının yerine daha ince dokulu, Gülibrişim (Albizzia julibrissin Duraz.), Huş (Betula verrucosa Ehrh.) veya beyaz hoş kokulu çiçekli Akasya (Robinia peudoacacia L.) kullanılmalıdır. Alanda vurgu yapılarak ilgi çekilmesi istenilen noktalara, renk etkisi ile etkili ve arka fon olabilecek Güvey kandili (Koelreuretia paniculata Laxm.), Ateş dikeni (Pyracantha coccinea Roem.), Kelebek çalısı (Buddleia davidii Franch., Oya ağacı (Lagerstromia indica L.), Koca yemiş (Arbutus unedo L.) dikilmelidir.

Oturma alanları ve çocuk oyun alanı çevresine çiçeklerinin kokusu ve gölge etkisi ile etkili Ihlamur (Tilia tomentosa Moench.) ve çocukların boyu ile orantılı olup renkleri ile dikkat çeken, kırmızı yapraklı Akçaağaç (Acer palmatum Thunb.) ve Oya ağacı (Lagerstromiaindica L.)önerilmiştir. Ayrıca bu bölümlerin yapısal elemanları sağlıklaştırılmalı ve modern tasarım getirilmelidir (Şekil 11).

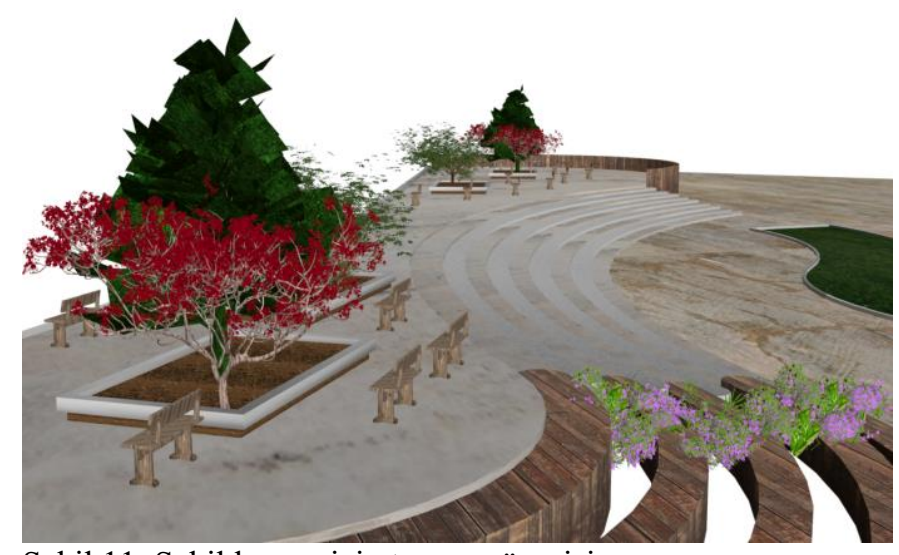

Şekil 11. Sahil kenarı için tasarım önerisi

Seyir terasının arka bölümünde yer alan oturma birimlerine işlevsel bir nitelik kazandırılması çok önemlidir. Günümüzde çim alana bakan ve geçişi sorunlu olan oturma birimleri yenilenerek önü küçük bir meydana dönüştürülmelidir. Meydanın zemininde Çanakkale Boğazının Çanakkale Savaşı Haritası'nın yer alması, ziyaretçilerin tarihi yerinde daha iyi analiz etmesini sağlayacaktır (Şekil 12). Çalışma alanını ziyaret eden kişilerin burada ‘Çanakkale Deniz Savaşı'nı yorumlaması sağlanabilir. 


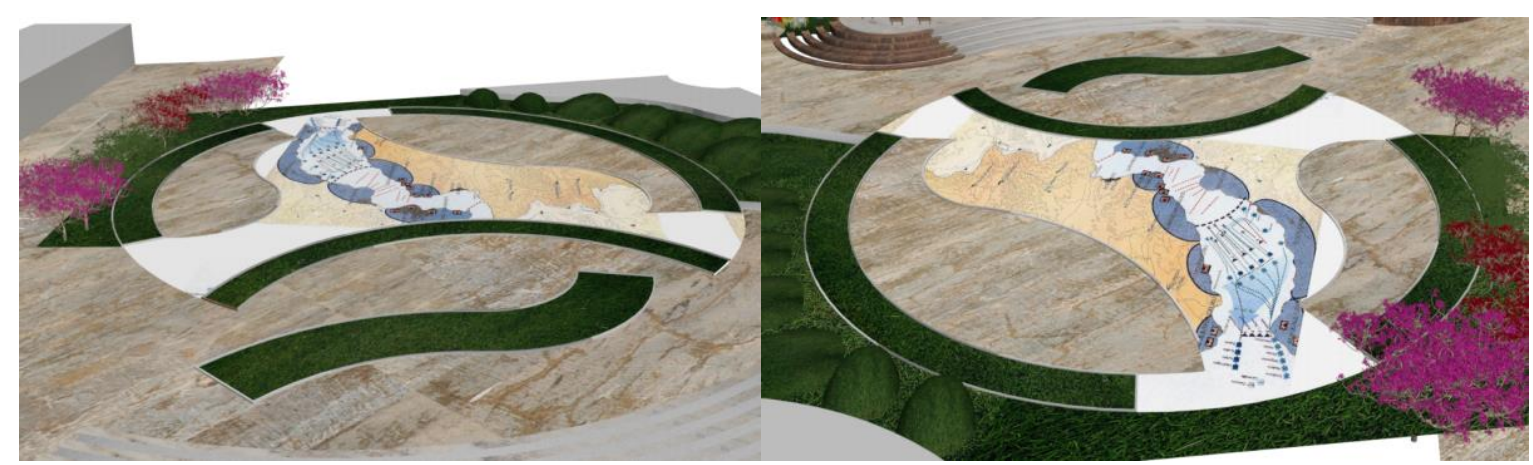

Şekil 12. Oturma alanlarına getirilen zemin önerisinin farklı açılardan görünüşü

\section{Kaynaklar}

Ahunbay, Z., 2004. Tarihî Çevre Koruma ve Restorasyon. Yapı Yayını: 28. 188s.

Anonim, 1981. Yurt Ansiklopesi: Cilt, 3. 7095s. İstanbul.

Anonim, 2005. https://www.canakkaletravel.com/galeri/cimenlik-kalesi.html (Erişim 28.12.2019).

Anonim, 2011. Çanakkale imar planı. Çanakkale Belediyesi İmar Müdürlüğü Kayıtları, 2012.

Anonim, 2012. TMMOB Peyzaj Mimarları Odası ve Çanakkale Valiliği ortak çalışması, (27 Ağustos-09 Eylül). http://www.peyzajmimoda.org.tr/genel/bizden_detay.php?kod=5276.

Anonim, 2013. Kültür ve Turizm Kayıtları. http://www.canakkale.bel.tr (Erişim 1 Mart 2013).

Anonim, 2015. http://www.kulturvarliklari.gov.tr/TR,133569/canakkale-cimenlik-kale-i-sultaniye-kalesi-restoreedil-.html. (Erişim 8.04.2017).

Anonim, 2016 a.http://www.turkcebilgi.com/ansiklopedi/kale. (Erişim:08.02.2016)

Anonim, 2016 b. http://tr.wikipedia.org/wiki/\%C3\%87anakkale_(il); https://www.google.com.tr/maps/place/Çanakkale, (Erişim:08.02.2016)

Anonim, 2016c. http://www.canakkalesehitlerimiz.com/kilitbahir_ve_cimenlik_kalesi.php. (Erişim:08.02.2016)

Anonim, 2017. Çanakkale İli 2016 Yılı İl Çevre Durum Raporu. T.C. Çanakkale Valiliği, Çevre ve Şehircilik İl Müdürlüğü, ÇED ve Çevre İzinlerinden Sorumlu Şube Müdürlüğü. (Erişim: 08.02.2018). file:///C:/Users/Fisun/Desktop/Canakkale_icdr2016.pdf

Anonim, 2018. https://www.gestcard.com.tr/gestcardweb/gestcard/blog/canakkalenin-yoncasi-kilitbahirkalesi.html (Erişim 28.12.2019).

$\begin{array}{lllll}\text { Anonim, } & \text { 2019a. } & \text { (Orhan } & \text { Özgülbaş'ın } & \text { fotoğrafi), }\end{array}$ https://www.kulturportali.gov.tr/turkiye/canakkale/gezilecekyer/cimenlik-kalesi.

Anonim, 2019b. https://i.pinimg.com/originals/ff/28/82/ff28824f32cd2ee1e58078b59fa15e6.jpg (Erişim: 02.01.2020).

Anonim, 2020. Google Earth' 2020. (Erişim: 29.12.2020).

Antrop, M., 2004. Landscape change and the urbanization process in Europe. Landscape and Urban Planning. (67): 9-26.

Ardıçoğlu, R., 2014. Kent içindeki tarihi alanların iyileştirilmesi ve kentle bütünleştirilmesi. Ankara Üniversitesi Fen Bilimleri Enstitüsü, Peyzaj Mimarlığı Anabilim Dalı, Yüksek Lisans Tezi. 210 s.

Bouzou, B., 2018. Technical co-operation and consultancy programme: historic towns. An integrated approach to cultural heritage. (J. Bold and R. Pickard eds.) The Council of Europe's. ISBN 978-92-871-8529-7: 109s. Strazbourg. https://rm.coe.int/an-integrated-approach-to-cultural-heritage-the-council-of-europes-te/1680792e6f (Erişim: 28.12.2020).

Can, C., 1993. Kentsel koruma alanları ve koruma sorunları. Ankara Ün. Dil ve Tarih-Coğrafya Fak. Dergisi. 1.2 (36): 307-314. dtcfdergisi.ankara.edu.tr/index.php/dtcf/article/download/4858/4765.

Çelik Çanga, A., Erduran Nemutlu, F., 2020. Landscape design for historic places. trends in landscape, agriculture, forest and nature science. Cambridge Scholar Publishing, ISBN(10):1:1-5275-4300-5, ISBN(13):978-1-5275-4300-3. p:146-153.

Çelik, D., Yazgan, M., 2007. Kentsel peyzaj tasarımı kapsamında tarihi çevre korumaya yönelik yasa ve yönetmeliklerin irdelenmesi. Bartın Orman Fakültesi Dergisi. 9(11): 1-10.

Çelik, D., Yazgan, M., 2009. Kentsel peyzaj tasarımı kapsamında tarihi çevre yenileme çalışmalarının araştırılması (Beypazarı örneği). Tekirdağ Ziraat Fakültesi Dergisi. 6(3): 235-244.

D.H.A., 2018. CNN Türk. (Erişim: 29.12.2020). https://www.cnnturk.com/yasam/ataturkun-gezi-teknesi-muzeolarak-ziyarete-acildi?page $=5$.

Hatip, S. M., 2009. Bahriye Şehri Kala-i Sultaniye (Çanakkale). Ankara Deniz Kuvvetleri Komutanlığı Basımevi Amirliği. s: 240. ISBN : 9789754095180 . Cebeci/Ankara.

https://earth.google.com/web/search/\%c3\%87anakkale+\%c3\%87imenlik+Kalesi/ 
ÇOMÜ Zir. Fak. Derg. (COMU J. Agric. Fac.)

2021: 9 (1): 57-69

ISSN: 2147-8384 / e-ISSN: 2564-6826

doi: 10.33202/comuagri.762995

Özsüle, Z., 2005. Geleneksel yerleşimlerin korunması açısından kültürel peyzaj değerlendirmesi: Mudanya örneği. İstanbul Üniversitesi, Fen Bilimleri Enstitüsü, Doktora Tezi.

Sevim, M., 2002. Gravürlerle Türkiye IV: Anadolu I. Kültür Bakanlığı Yayımlar Dairesi Başkanlığı Yayınları: Cilt 1. ISBN: 9751717434. 263s. Ankara.

Tiesdell, S., Oc, T., Heath, T. 1996. Revitalizing Historic Urban Quartes. Cornwall Architectural Press: 135s.

Tombul, M., 2015. Çanakkale Kültür Envanteri. Matsis Matbaa, Zero Prodüksiyon Ltd. Şti. ISBN 978-6054701-63-6. 670s. İstanbul.

Utkular, İ., 1953. Çanakkale Boğazındaki Fatih Kaleleri. İstanbul Teknik Üniversitesi Mimarlık Fakültesi Yayınları. Pulhan Matbaası. 9s. İstanbul.

Uzunçarşı11, İ. H., 1991. Osmanlı Tarihi: Cilt, 1. 639s. Ankara. 